\title{
PENERAPAN TEKNIK L-BATO UNTUK MENINGKATKAN KETERAMPILAN MENULIS TEKS OPINI PADA SISWA KELAS XII SMA
}

\author{
Puji Handayani \\ SMA N 1 Muntilan, Kab. Magelang, Jawa Tengah \\ Email: jihanbinawa@gmail.com
}

\begin{abstract}
Abtrak
Penelitian ini bertujuan untuk memberikan penjelasan tentang Teknik L-Bato sebagai salah satu teknik pembelajaran menulis teks opini, mendeskripsikan penerapan Teknik L-Bato dalam pembelajaran menulis teks opini, dan mengetahui efektifitas Teknik L-Bato untuk penerampilan menulis teks opini. Penelitian ini menerapkan metode eksperimen dengan desain One Group Pretest-Posttest Design (Single Group Design), yakni menggunakan satu kelompok saja. Pada kelompok tersebut dilakukan pretes kemudian diberi perlakuan. Setelah itu barulah kelompok tersebut dilakukan postes. Penelitian ini melibatkan 36 siswa kelas XII SMA. Pengambilan data berlangsung dari bulan Januari sampai dengan Maret 2018. Hasil penelitian menunjukkan bahwa Teknik L-Bato terbukti efektif untuk menerampilkan peserta didik dalam menulis teks opini.
\end{abstract}

Kata kunci: teknik L-Bato, efektivitas, teks opini, eksperimen.

\section{PENDAHULUAN}

Implementasi Kurikulum 2013 membawa perubahan mendasar dalam pembelajaran bahasa Indonesia. Perubahan itu mencakupi beberapa hal, yakni (1) pendekatan, (2) model pembelajaran, (3) genre teks, dan (4) sistem penilaian. Di antara perubahan-perubahan itu, perubahan genre teks membawa dampak yang besar dalam pembelajaran. Pembelajaran berbasis teks menyodorkan genre teks yang sama sekali berbeda dengan materi pembelajaran sebelumnya. Dalam kurikulum sebelumnya, jenis teks hanya mencakupi (1) narasi, (2) deskripsi, (3) argumentasi, (4) eksposisi, dan (5) persuasi, sedangkan Kurikulum 2013 menyajikan teks yang lebih variatif.

Teks anekdot, eksplanasi, rekon, prosedur kompleks, eksposisi, editorial, laporan hasil observasi, dan teks cerita sejarah merupakan genre teks yang dikomposisikan dalam kurikulum 2013. Meskipun ada banyak genre teks, dilihat dari dari sifatnya, teks dapat diklasifiksikan menjadi 3, yakni (1) teks opini, (2) teks faktual, dan (3) teks imajinatif. Teks opini mewujud dalam teks eksposisi, teks ulasan, dan teks editoral. Teks faktual muncul dalam bentuk teks laporan hasil observasi, teks eksplanasi, dan teks berita. Teks imajinatif mencakupi teks anekdot, teks cerpen, dan novel.

Di antara sekian banyak teks yang dikomposisikan dalam struktur kurikulum 2013, teks opini cenderung lebih problematis. Pertama, pemahaman peserta didik terhadap teks opini belum utuh. Peserta didik disinyalir belum memahami karakteristik teks opini, bahkan belum bisa membedakan teks opini dari teks lainnya seperti teks berita, teks eksplanasi, atau teks rekon. Kedua, peserta didik belum mengetahui teknik menulis yang tepat. Ketiga, peserta didik merasa tidak berbakat menulis.

Teks opini adalah salah satu genre teks yang berisi gagasan, penilaian, atau pendapat seseorang tentang suatu topik. Perbedaannya dengan teks berita adalah bahwa teks opini bersumber pada pendapat penulis, sedangkan teks berita bersumber pada peristiwa yang benar-benar terjadi, atau keadaan yang benar-benar ada. Perbedaan lainnya, teks opini bersifat subjektif, sedangkan teks berita bersifat objektif. 
Susena (1997:54) menuturkan bahwa opini merupakan pendapat terhadap suatu masalah yang ada dalam masyarakat. Dalam konteks jurnalistik, opini adalah bentuk tulisan pendek mengenai suatu masalah yang berisi pendapat penulisnya. Menukik pada kontennya, teks opini, menurut Hutabarat dan Pudjomartono (1995:42), masalah yang dibicarakan dalam opini adalah masalah yang aktual dan faktual. Opini mengandung unsur subyektifitas, bukan hanya fakta.

Mengacu pada pernyataan Pudjomartono bahwa teks opini hanya membahas masalah yang aktual dan faktual maka wajar jika opini muncul sebagai bentuk respon terhadap suatu peristiwa, kejadian, atau fenomena. Opini dapat muncul secara pribadi (individu) atau muncul secara kolektif. Di media masa, opini pribadi muncul dalam bentuk tulisan artikel opini, sedangkan opini kolektif muncul dalam bentuk tajuk rencana (teks editorial).

Agar opini bisa diketahui oleh masyarakat luas, biasanya dilakukan publikasi. Di media cetak, rubrik untuk menampung tulisan opini sangat dibatasi oleh ruang. Oleh karenanya, opini biasa muncul dalam bentuk artikel pendek. Hal ini sejalan dengan pernyataan Susena (1997: 103) yang menyatakan bahwa opini langsung berisi tubuh yang menghadirkan suatu permasalahan kemudian diikuti pendapat penulis mengenai masalah tersebut. Oleh karena itu, opini biasanya berupa tulisan pendek saja.

Pembatasan ruang di media cetak menuntut para penulis opini untuk bisa mengemas tulisannya seefektif mungkin agar penalaran dan pemikirannya mudah dipahami oleh pembaca. Diperlukan kemahiran khusus untuk membahasakan opini dalam kalimat yang efektif, penalaran yang logis, dan argumentasi yang didukung oleh data dan fakta yang akurat. Untuk itulah penulisan teks opini dilatihkan dalam pembelajaran bahasa Indonesia.

Sebagai bentuk respons atas suatu fenomena, peristiwa, kejadian, dan kebijakan, teks opini didominasi pendapat penulis. Sebagai ungkapan pendapat, teks opini harus berisi argumen yang kuat. Argumentasi menjadi unsur penting dalam opini. Ada hal yang harus diperhatikan saat menulis. Keraf (1983:101-102) mensyaratkan kompetensi penulis argumentasi yang mencakupi dua hal; (1) penulis harus mengetahui subyek yang akan dikemukakannya, sekurang-kurangnya mengetahui prinsip ilmiahnya, (2) penulis bersedia mempertimbangkan pandangan-pandangan lain yang bertentangan dengan pandangan-pandangannya.

Pendapat Keraf tersebut kiranya dapat dimaknai bahwa dalam teks opini penulis diwajibkan berpendapat secara ilmiah dan menghindarkan dari memaksakan pendapat. Setiap penulis teks opini harus menyadari bahwa selalu ada kemungkinan orang lain berbeda pendapat. Oleh karena itu kekuatan teks opini bergantung pada kekuatan argumentasi yang diungkapkan, akurasi data yang mendukung argumentasi, dan kekuatan bukti-bukti pendukung, serta kelogisan penalaran yang digunakan.

Seturut dengan karakteristik teks opini, Achmadi (1988:90) menggolongkan teks opini sebagai wacana argumentatif yang memiliki ciri-ciri khas, yakni (1) membantah atau menentang suatu usul atau pernyataan tanpa berusaha meyakinkan atau untuk mempengaruhi pembaca agar memihak dengan tujuan utama kemungkinan ini adalah semata-mata untuk menyampaikan pandangan, (2) mengemukakan suatu alasan untuk bertahan sedemikian rupa dengan mempengaruhi keyakinan pembaca agar menyetujuinya, (3) mengusahakan pemecahan masalah; dan (4) mendiskusikan persoalan tanpa perlu menyampaikan suatu penyelesaian.

Pada kebanyakan orang menulis menjadi suatu tantangan. Ini disebabkan oleh suatu pandangan bahwa pada dasarnya setiap orang bisa berpendapat dan memiliki opini untuk diungkapkan, namun kesulitan untuk mengungkapkannya. Jadi, tantangan dalam menulis pada dasarnya tidak terletak pada 'apa yang akan dituliskan', tetapi pada 'bagaimana menuliskannya'. Itulah sebabnya, beberapa ahli selalu memasukkan pembuatan draf dalam proses menulis. Draf dalam pembuatan karangan atau tulisan tersebut lazim disebut kerangka karangan (outline). 
Nursito (2000:5-4) menyatakan bahwa kerangka karangan (outline) adalah rencana kerja yang memuat garis-garis besar atau susunan pokok pembicaraan sebuah karangan yang akan ditulis. Sedangkan menurut Soeparno (2004:38), kerangka karangan adalah kerangka tulis yang menggambarkan bagian-bagian atau butir-butir isi karangan dalam tatanan yang sistematis. Bersandar pada dua pendapat ini dapatlah dikatakan bahwa kerangka merupakan alat bantu yang berupa draf, rancangan, atau plafon sebuah tulisan.

Outline menjadi sangat penting dalam proses menulis karena menjadi alat bantu penulis dalam mengarahkan gagasannya dalam bentuk tulisan. Setidaknya, ada empat fungsi outline, yakni (1) membantu penulis dalam mengorganisasi gagasan, (2) membuat sistematika tulisan, (3) mempermudah penulis mencari sumber dan data pendukung, dan (4) menghindarkan penggarapan topik secara berulang. Keempat manfaat outline tersebut dipandang dari sisi penulis. Pembuatan outline juga --secara tidak langsung-- bermanfaat bagi pembaca. Membaca tulisan yang dikembangkan dari outline akan mempermudah pembaca memahami tulisan yang dibacanya karena pasti lebih sistematis dan terarah.

Teknik L-Bato adalah sebuah formulasi sederhana yang merupakan susunan langkah dalam menulis teks opini. Teknik ini merupakan kependekan dari Lead, Bahasan Lead, dan Topikalisasi. L-Bato merupakan outline simpel yang akan menjadi tantangan tersendiri dalam menulis teks opini publikatif.

Dalam kajian jurnalistik, Lead adalah teras yang biasanya digunakan untuk mengawali berita. Oleh karenanya sering disebut teras berita. Namun, Ismail Marahimin dalam bukunya Menulis Secara Populer (1999) meneguhkan bahwa jenis tulisan selain berita pun memerlukan lead. Dalam teks opini, leads memiliki dua fungsi utama, (1) sebagai daya tarik bagi pembaca, (2) sebagai pintu masuk bagi penulis untuk memulai tulisannya. Lead bisa diambil dari kutipan pernyataan tokoh, penggalan puisi, petikan syair lagu, atau hal lain yang memiliki daya pikat.

Bagian kedua dari teknik L- Bato adalah bahasan lead. Setelah lead ditentukan, penulis akan lebih mudah masuk ke dalam isi tulisan dengan terlebih dahulu membahas lead. Pembahasan lead ini akan menjadi tantangan menarik bagi penulis pemula untuk memulai menuangkan gagasan dan ide-idenya. Dalam tahap ini, penulis akan mengaitkan lead dengan topik yang akan dibahas. Di sinilah pintu masuk bagi penulis untuk mulai menuangkan opininya.

Topikalisasi merupakan bagian ketiga dalam teknik L- Bato. Topikalisasi menyerupai outline pada umumnya. Hanya saja, topikalisasi ini akan muncul dalam bentuk frasa yang menarik. Tidak seperti outline pada umumnya yang ketika tulisan sudah jadi tidak ada jejak outline-nya, dalam topikalisasi akan muncul sebagai subtopik-subtopik yang menggambarkan alur berpikir penulis.

\section{METODE PENELITIAN}

Penelitian ini menerapkan metode eksperimen yakni penelitian yang memberikan perlakuan (treatment) kepada objek penelitian. Pengaruh dari treatmen (perlakuan) tersebut yang akan diteliti. Namun, eksperimen dilakukan secara semu, maka disebut eksperimen quasi (quasi experiment). Penyebutan semu karena dalam penelitian ini kelompok eksperimen yang digunakan menggunakan kelompok yang sudah terbentuk, berupa kelas. Peneliti tidak membentuk sendiri kelompok eksperimen dengan kriteria tertentu. Dalam penelitian ini penulis menggunakan desain one group pre test - post test. Desain seperti ini juga lazim disebut One Group PretestPosttest Design (Single Group Design). Seperti yang tersurat dalam namanya, desain ini hanya menggunakan satu kelompok eksperimen tanpa kelompok pembanding. Sebagai gambaran, berikut ini bagan desain penelitian pretest - postest satu kelompok. 


\section{$\mathbf{O}_{1}----->\mathbf{X}------>\mathbf{O}_{2}$}

Keterangan :

- $\mathrm{O}_{1} \quad=$ pretes

- $\mathrm{X}=$ perlakuan (treatment)

- $\mathrm{O}_{2} \quad=$ postes

Perbedaan antara $0_{1}$ dan $0_{2}$ yakni $0_{2}-0_{1}$ merupakan efek atau pengaruh dari treatment yang diberikan (Arikunto, 2014:124).Objek penelitian ini adalah siswa kelas XII MS1 SMA Negeri 1 Muntilan TP 2017/2018 sejumlah 36 orang yang otomatis menjadi populasi. Pemilihan objek tersebut karena peneliti mengajar di kelas tersebut. Ke-36 siswa tersebut menjadi sekaligus menjadi sampel. Data yang dihimpun dalam penelitian ini adalah nilai teks opini yang disusun siswa, baik pada saat pretes maupun postes. Data yang diperoleh melalui tes menulis kemudian dinilai dengan rubrik penilaian yang mencakupi lima aspek penting yakni struktur teks, kekuatan argumen, kebahasaan, mekanik (meliputi penggunaan ejaan dan tanda baca yang taat asas), dan kelayakan publikasi. Secara rinci, rubrik penilaian tertera sebagai berikut.

\begin{tabular}{|c|c|c|}
\hline NO & INDIKATOR & SKOR \\
\hline \multirow[t]{5}{*}{1} & Struktur Teks Opini & \\
\hline & $\begin{array}{l}\text { a. Teks berbentuk teks opini yang didukung tiga aspek (tesis, argumen, dan penegasan } \\
\text { ulang) }\end{array}$ & 4 \\
\hline & b. Teks berbentuk teks opini namun hanya didukung dua aspek & 3 \\
\hline & c. Teks berbentuk teks opini namun hanya didukung satu aspek & 2 \\
\hline & d. Teks tidak didukung oleh aspek-aspek yang merupakan ciri teks opini. & 1 \\
\hline \multirow[t]{5}{*}{2} & Opini (Kekuatan Argumen) & \\
\hline & a. Opini sangat kuat, argumen yang sangat logis, sistematis, disertai bukti dan data. & 4 \\
\hline & $\begin{array}{l}\text { b. Opini kuat, didukung dengan argumen yang cukup logis, sistematis, namun tidak } \\
\text { diperkuat data dan bukti }\end{array}$ & 3 \\
\hline & $\begin{array}{l}\text { c. Opini kurang kuat, belum didukung dengan argumen yang logis, sistematis, serta } \\
\text { tidak diperkuat data dan bukti }\end{array}$ & 2 \\
\hline & $\begin{array}{l}\text { d. Opini lemah, tidak didukung dengan argumen yang logis dan sistematis, serta } \\
\text { tidak diperkuat data dan bukti }\end{array}$ & 1 \\
\hline \multirow[t]{5}{*}{3} & Bahasa & \\
\hline & a. Teks ditulis dengan bahasa yang sangat informatif, efektif, dan komunikatif. & 4 \\
\hline & Teks ditulis dengan bahasa yang cukup informatif, efektif, dan komunikatif. & 3 \\
\hline & Teks ditulis dengan bahasa yang kurang informatif, efektif, dan komunikatif. & 2 \\
\hline & d. Teks ditulis dengan bahasa yang tidak informatif, efektif, dan komunikatif. & 1 \\
\hline \multirow[t]{5}{*}{4} & Mekanik & \\
\hline & $\begin{array}{l}\text { a. Teks ditulis dengan sangat memperhatikan kaidah kebahasaan, ejaan, dan tanda } \\
\text { baca. }\end{array}$ & 4 \\
\hline & $\begin{array}{l}\text { b. Teks ditulis dengan cukup memperhatikan kaidah kebahasaan, ejaan, dan tanda } \\
\text { baca. }\end{array}$ & 3 \\
\hline & $\begin{array}{l}\text { c. Teks ditulis dengan kurang memperhatikan kaidah kebahasaan, ejaan, dan tanda } \\
\text { baca. }\end{array}$ & 2 \\
\hline & $\begin{array}{l}\text { d. Teks ditulis dengan tidak memperhatikan kaidah kebahasaan, ejaan, dan tanda } \\
\text { baca. }\end{array}$ & 1 \\
\hline
\end{tabular}




\begin{tabular}{lcc}
\hline NO & \multicolumn{1}{c}{ INDIKATOR } & SKOR \\
\hline 5 & $\begin{array}{l}\text { Kelayakan publikasi } \\
\text { a. }\end{array}$ & $\begin{array}{l}\text { Teks opini yang ditulis sangat layak dipublikasikan (menarik, merangsang minat } \\
\text { baca, penting, aktual, informatif). }\end{array}$ \\
& $\begin{array}{l}\text { Teks opini yang ditulis cukup layak dipublikasikan (kurang menarik, kurang } \\
\text { berangsang minat baca, penting, aktual, informatif). }\end{array}$ & 3 \\
& c. $\quad \begin{array}{l}\text { Teks opini yang ditulis kurang layak dipublikasikan (kurang menarik, tidak } \\
\text { merangsang minat baca, penting, aktual, tidak informatif). }\end{array}$ & 2 \\
d. & $\begin{array}{l}\text { Teks opini yang ditulis tidak layak dipublikasikan (tidak menarik, tidak merangsang } \\
\text { minat baca, kurang penting, kurang aktual, tidak informatif. }\end{array}$ & 1 \\
\hline & \multicolumn{1}{c}{ JUMLAH } & 20 \\
\hline
\end{tabular}

Tabel 1: Rubrik Penilaian Teks Opini (editorial)

Hasil dari penilaian tersebut akan menjadi data untuk kemudian diolah dengan rumus statistik untuk mengetahui efektivitas teknik L-Bato yang diujikan. Adapun urutan pengolahan data terinci berikut ini.

\section{1) Mencari gain (selisih) antara postes dan pretes}

$d=T_{2}-T_{1}$

Keterangan :

$d=$ selisih postes dan pretes

$T_{1}=$ nilai postes

$T_{2}=$ nilai pretes

\section{2) Mencari Mean (rerata)}

$M d=\frac{\sum d}{N}$

Keterangan :

$M d=$ mean gain (rerata selisih antara pretes dan postes)

$d=$ selisih postes dan pretes

$N=$ jumlah sampel (siswa)

\section{3) Melakukan Kuadrat Deviasi}

$\sum X^{2} d=\sum d^{2}-\frac{\left(\sum d\right) 2}{N}$

Keterangan :

$\sum X^{2} d=$ jumlah kuadrat deviasi

$\sum d^{2}=$ jumlah selisih (gain) setelah dikuadratkan

$N=$ jumlah sampel/banyaknya subjek

4) Melakukan Uji t

t-hitung $=\frac{M d}{\sqrt{\frac{\sum x 2 d}{N(N-1)}}}$ 


\section{5) Menafsirkan nilai $t$}

Penafsiran nilai t dilakukan dengan membandingkan t-hitung dengan t-tabel.

Uji hipotesis dilakukan setelah mendapatkan nilai t-hitung. Nilai yang didapat tersebut dibandingkan dengan t-tabel. Hasil dari perbandingan tersebut akan memunculkan pernyataan berikut.

a. Jika nilai t-hitung $>$ t-tabel, Hk (Hipotesis Kerja) diterima sedangkan Ho (Hipotesis nol) ditolak

b. Jika nilai t-hitung < t-tabel, Hk (Hipotesis Kerja) ditolak sedangkan Ho (Hipotesis nol) diterima

Sebelum membandingkan t-hitung dan t-tabel, terlebih dahulu ditentukan derajat kebebasan dengan menggunakan rumus $=$

$d f / d b=(n-1)$

Setelah menentukan $d b$ akan diperoleh nilai t tabel pada taraf signifikansi 5\% dan 1\%. Yang dimaksud dengan $d b / d f$ (derajat bebas/ degree of freedom) adalah banyaknya amatan bebas dari total amatan dalam sampel (N) dikurangi banyaknya pembatasan dari jumlah amatan (1).

\section{HASIL DAN PEMBAHASAN}

Penelitian dilaksanakan dalam pembelajaran di kelas XII A1 menggunakan sampling jenuh, yakni seluruh siswa dalam kelas tersebut dijadikan responden. Pelaksanaan penelitian mencakupi tiga langkah, yakni perencanaan, pelaksanaan, dan penilaian. Pada tahap perencanaan pembelajaran, peneliti mempersiapkan segala hal yang akan digunakan dalam penelitian. Halhal yang dipersiapkan antara lain memberikan sosialisasi kepada responden, menyusun Rencana Pelaksanaan Pembelajaran, menyusun perangkat pretest dan postest, menyiapkan rubrik penilaian, dan melakukan pretest.

Pretes dilakukan pada Selasa, 2 Februari 2018. Peneliti memberikan tugas menulis artikel opini dengan 3 topik: (1) Pelaksanaan Full Day School, (2) Penenggelaman Kapal Asing, dan (3) Sinetron Remaja. Banyak siswa yang menjadikan topik sekaligus menjadi judul. Namun ada juga yang sudah mengubah topik menjadi judul yang lebih spesifik dan fokus. Dari topik-topik tersebut Full Day School merupakan topik yang paling banyak dipilih siswa. Sebanyak 21 siswa (59\%) memilihnya. Bisa jadi, banyaknya siswa yang memilih topik ini karena memang mereka mengalami sendiri implementasi full day school di sekolah. Topik kedua, penenggelaman kapal asing, dipilih oleh 12 siswa (33\%), dan sinetron remaja dipilih hanya 3 orang siswa (8\%). Untuk topik yang terakhir ini, bisa jadi kurang dikuasai oleh siswa karena mereka jarang menonton sinetron Indonesia. Data tersebut dapat dimaknai bahwa topik-topik yang dekat dengan siswa akan lebih banyak dipilih karena siswa lebih menguasainya. 


\section{PEMILIHAN TOPIK}

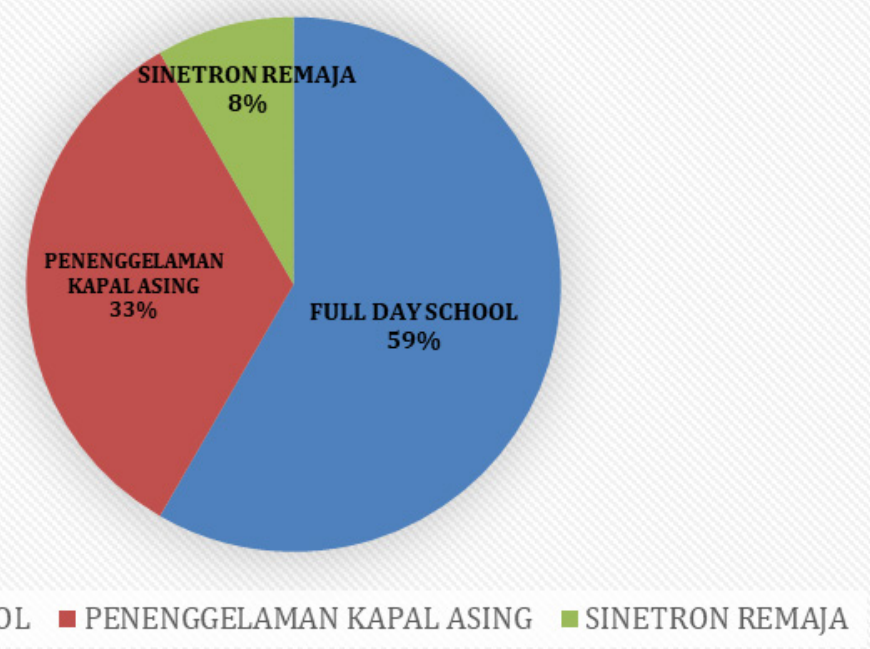

Gambar 1: Proporsi Pemilihan Topik Artikel Opini.

Artikel opini yang ditulis oleh siswa setelah dinilai berdasarkan rubrik menunjukkan bahwa nilai keterampilan menulis opini siswa belum optimal. Dilihat dari struktur teks yang baru mencapai $63 \%$, berarti banyak artikel belum memiliki struktur yang benar. Dilihat dari kekuatan opininya, tulisan siswa juga belum optimal karena tidak didukung data dan bukti. Hal tersebut menyebabkan pencapaian nilai opini pada pretes baru $64 \%$. Efektivitas penggunaan bahasa baru menyentuh angka $65 \%$ karena banyak tulisan siswa yang belum menerapkan kalimat efektif.

Selain itu, secara mekanik, penggunaan tanda baca dan ejaan juga baru mencapai angka $63 \%$. Ini berarti bahwa penerapan ejaan dan tanda baca belum diperhatikan dengan baik sehingga belum digunakan secara taat asas. Dari segi kelayakan publikasi mendapatkan capaian paling rendah, yakni hanya 53\%. Hal ini berarti artikel siswa belum layak dipublikasikan. Ketidaklayakan ini pada umumnya disebabkan oleh menarik tidaknya bentuk artikel, judul yang kurang merangsang minat baca, dan aktualitas topik tulisan yang rendah.

Penelitian dilakukan dengan memberikan perlakuan tentang bagaimana menulis artikel dengan Teknik L-Bato. Perlakuan diberikan dalam tiga kali proses pembelajaran yang mencakupi perencanaan (pre-writing), penyusunan teks (writing), dan penyuntingan (editing).

1. Merancang Teks Opini (pre-writing)

Pada Selasa, 6 Februari 2018 di Kelas XII MS 1, siswa diajak untuk merencanakan teks opini. Pada tahap perancangan (pre writing), siswa mulai memilih topik yang diminati. Ada beberapa topik yang mereka pilih; pendidikan, ketenagaan, politik, dan lingkungan. Setelah itu, mereka menyusun lead (L). Pada saat penyusunan lead, siswa diperbolehkan membuka HP untuk menemukan lead yang paling pas untuk tulisannya. Pada umumnya mereka mengutip berita, menukil lirik lagu, mengutip pernyataan tokoh, dan menyarikan pendapatnya sendiri tentang topik yang dipilih.

Setelah lead ditemukan, siswa mulai menyiapkan pembahasan lead, dan menyusun topikalisasi. Penyusunan topikalisasi ini mirip dengan menyusun gagasan utama/ pikiran pokok untuk kemudian dikembangkan menjadi teks. Selama pembelajaran berlangsung, siswa tampak antusias dalam pembelajaran. Antusiasme ini terutama 
tampak saat mereka harus menyusun lead artikel (teras). Hampir semua responden tertarik mencermati contoh-contoh artikel opini yang dijadikan model teks. Beberapa siswa masih menanyakan apakah rancangan yang disusun sudah sistematis atau belum. Peneliti mendampingi untuk memastikan rancangan yang disusun siswa sudah dapat dikembangkan menjadi teks opini.

2. Penyusunan teks opini

Tahap ke-2 (writing) dilaksanakan pada Jumat, 9 Februari 2018. Pada tahap ini siswa mengembangkan rancangan yang sudah disusun. Untuk memperkuat argumen dalam teks opini mereka, diperlukan data dan bukti yang kuat. Oleh karena itu, siswa diperbolehkan mengakses internet untuk mencari informasi, data, dan bukti secara daring.

Pada tahap ini, ternyata banyak siswa yang justru tergiring pada opini orang lain yang tertulis dalam artikel yang publish di internet. Wajarlah jika pada tahap ini banyak pertanyaan dari siswa untuk meyakinkan apakah bukti yang mereka dapatkan bisa mendukung argumen yang dibangun dalam teks opininya.

Peneliti beberapa kali mengingatkan agar tidak melakukan plagiasi dalam penelusuran data dan bukti.

3. Penyuntingan

Tahap penyuntingan (editing) dilaksanakan pada Selasa, 13 Februari 2018. Di dalam tahap ini siswa dibimbing untuk melakukan penyempurnaan tulisannya. Penyuntingan diarahkan pada tiga hal, yakni struktur teks, penerapan ejaan dan tanda baca, serta struktur kalimat efektif. Pada tahap ini sering terjadi diskusi dengan teman duduk untuk saling mengoreksi teks mereka masing-masing. Pada umumnya, porsi besar penyuntingan terletak pada pengalimatan. Banyak siswa yang kurang memahami struktur kalimat yang efektif sehingga kalimat yang disusun cenderung panjang-panjang dan berputar-putar. Namun demikian, mereka tetap melakukan perbaikan atas artikel yang disusunnya.

Pos-tes dilaksanakan pada Selasa, 20 Februari 2018. Setelah dua minggu mendapatkan perlakuan tentang cara menyusun artikel opini dengan teknik L-Bato, siswa diberi tugas untuk menyusun artikel. Untuk penugasan kedua ini siswa dibebaskan dalam memilih topik. Hal ini berkaca pada hasil pretes tentang kekuatan opini. Pada saat itu, siswa mampu beropini secara kuat apabila mereka menguasai benar topik yang dibahasnya.

Hasil postes menunjukkan capaian yang lebih baik. Artikel sudah menunjukkan struktur yang utuh, yakni meliputi tesis argumen penegasan ulang. Hal ini ditunjukkan dengan capaian yang mencapai angka 91\%. Angka tersebut diperoleh dari jumlah skor capaian 130 dari skor maksimal 144. Kekuatan opini juga sudah tampak pada postes ini. Siswa mampu meraih jumlah nilai 123 dari skor maksimal 144 atau meraih hasil $85 \%$.

Dilihat dari penggunaan bahasa juga sudah mulai membaik. Kalimat sudah mulai tertata dan efektif, bahasanya komunikatif. Hal ini ditunjukkan dengan nilai capaian 124 dari skor maksimal 144 (86\%). Unsur mekanik (penerapan ejaan dan tanda baca) juga sudah mulai diperhatikan. Capaian untuk aspek unsur mekanik ini menyentuh skor 115 dari skor maksimal 144 atau mencapai $80 \%$. Capaian pada kelayakan publikasi juga menunjukkan peningkatan jumlah menjadi 131 dari skor maksimal 144 atau menyentuh angka 90\%.

Kenaikan capaian dari pretes ke postes dapat dilihat dalam tabel berikut ini. Tabel berikut menunjukkan kenaikan capaian dari skor pretes ke skor postes. 


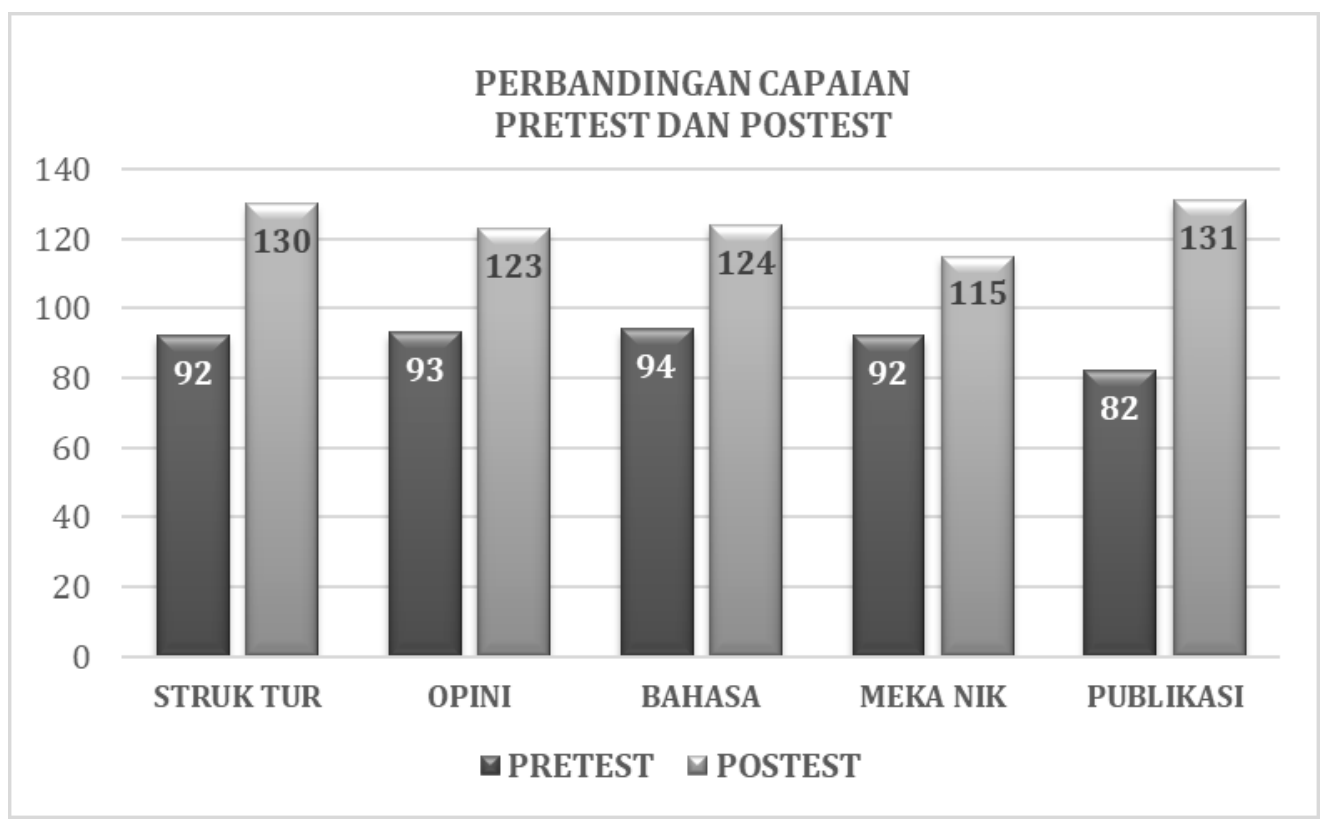

Gambar 1: Grafik Perbandingan Capaian Pretes dan Postes

Tampak pada tabel bahwa semua aspek artikel mengalami kenaikan. Pada aspek struktur teks, peningkatan mencapai $26 \%$. Angka ini cukup tinggi dibandingkan dengan kenaikan skor pada aspek opini yang mencapai $21 \%$. Angka yang sama juga terjadi pada aspek bahasa, yakni $21 \%$. Peningkatan terkecil terjadi aspek mekanik (penerapan tanda baca dan ejaan) yang hanya meningkat sebesar $16 \%$, sedangkan kenaikan tertinggi terjadi pada aspek kelayakan publikasi, yakni 34\%.

Selisih nilai hasil pretes dan postes digunakan untuk melakukan pengolahan data berikutnya. Pengolahan data dimaksudkan untuk membuktikan apakah peningkatan skor dari pretes ke postes bermakna signifikan atau tidak. Untuk membuktikan signifikansi kenaikan skor dimaksud diperlukan beberapa tahapan.

a. Menentukan Gain Score

$$
\begin{aligned}
& d=T_{2}-T_{1} \\
& d=2265-3115 \\
& d=\mathbf{8 5 0}
\end{aligned}
$$

b. Menentukan Mean Gain

$$
\begin{array}{ll}
M d=\frac{\sum d}{N} \\
\sum d \quad=850 \\
N=36 & \\
M d & =\frac{850}{36} \\
M d & =23,6
\end{array}
$$


c. Menentukan kuadrat deviasi

$\sum X^{2} d=\sum d^{2}-\frac{\left(\sum d\right) 2}{N}$

$\sum d \quad=850$

$\Sigma_{d} 2=23600$

$N=36$

$\Sigma_{X} 2_{d}=23600-\frac{850^{2}}{36}$

722500

$=23600-36$

$=23600-20069,44$

$=\mathbf{3 5 3 0}, \mathbf{5 6}$

d. Melakukan Uji- $t$

t-hitung $=\frac{M d}{\sqrt{\frac{\sum x 2 d}{N(N-1)}}}$

Diketahui:

Md $=23,6$

$\sum x^{2} d=23,579$

$N=36$

$t_{\text {hitung }}=\frac{23,6}{\sqrt{\frac{3530,56}{36(36-1)}}}$

23,6

$=\sqrt{\frac{3530,56}{36 \times 35}}$

$=\frac{23,6}{\sqrt{\frac{3530,56}{1260}}}$

$=\frac{23,6}{\sqrt{2,8}}$

$\frac{23,6}{1,67}$

$=14,131$ 
e. Menafsirkan $t$

Diketahui :

Taraf signifikansi $\quad=0,05$

$d f / d b \quad=\mathrm{N}-1$

$=36-1$

$=35$

t-hitung $\quad=14,131$

t-tabel $\quad=1,690$

Dengan t-hitung sebesar 14,131 dan t-tabel 1,690 maka: $\boldsymbol{t}$-hitung $\geq \boldsymbol{t}$-tabel $(14,131 \geq 1,690)$. Dengan demikian Hk (hipotesis kerja) diterima, dan H0 ditolak. Dengan demikian, hipotesis kerja (Hk) yang berbunyi terdapat perbedaan yang signifikan pada penggunaan Teknik L-Bato terhadap keterampilan menulis teks opini pada siswa kelas XII MS 1 SMA N 1 Muntilan, dapat diterima pada taraf signifikansi 0,05. Mengacu pada rumusan tujuan penelitian ini, yakni mengetahui efektivitas Teknik L-Bato untuk penerampilan menulis teks opini sudah tercapai dan dapat dibuktikan bahwa Teknik L-Bato efektif untuk menerampilkan siswa dalam menulis teks opini.

\section{KESIMPULAN DAN SARAN}

Mengacu pada pembahasan dalam bagian sebelumnya, penelitian ini berhasil mencapai 3 tujuan utama penelitian untuk mengetahui hakikat Teknik L-Bato sebagai salah satu teknik pembelajaran untuk menerampilkan peserta didik dalam menulis teks opini; mengetahui langkah-langkah pembelajaran untuk mengimplementasikan Teknik L-Bato sebagai salah satu teknik pembelajaran untuk menerampilkan peserta didik dalam menulis teks opini; dan mengetahui efektivitas Teknik L-Bato untuk penerampilan menulis teks opini.

1. Teknik L-Bato adalah sebuah formulasi sederhana yang merupakan susunan langkah dalam menulis teks opini. Teknik ini merupakan kependekan dari Lead, Bahasan Lead, dan Topikalisasi. L-Bato merupakan outline simpel yang akan menjadi tantangan tersendiri dalam menulis teks opini publikatif.

2. Teknik L-Bato sesuai dibelajarkan dengan model pembelajaran Problem Based Solving dan bersandar pada Pendekatan Saintifik (Scientific Approach). Model pembelajaran Problem Based Learning memiliki sintak 1) orientasi, 2) pengorganisasian, 3) pembimbingan, 4) pengembangan hasil karya, dan 4) evaluasi hasil karya.

3. Hasil penelitian, penyajian data, dan analisis data, menyatakan bahwa terdapat perbedaan yang siginifikan antara teknik konvensional dan Teknik L-Bato dalam penerampilan menulis teks opini (teks editorial) pada siswa kelas XII MS 1 SMA Negeri 1 Muntilan. Hal ini ditunjukan dengan hasil t-hitung $>$ t-tabel, yakni $(14,131>1,690)$. Dengan demikian, dapat disimpulkan bahwa Ho ditolak dan Hk diterima.

Jika hipotesis kerja (Hk) diterima, berarti Teknik L-Bato terbukti efektif untuk menerampilkan siswa dalam menulis teks opini (editorial).

Berdasarkan hasil penelitian, analisis data dan uji hipotesis yang dilakukan maka dapat disarankan hal-hal berikut ini.

1. Dalam memilih topik artikel opini sebaiknya siswa diberi kebebasan untuk menentukan topik. Sebab, topik yang lebih dekat dengan siswa akan membantu mereka untuk mengembangkan secara lebih sistematis dan logis. Mereka akan lebih mudah menemukan bukti-bukti untuk mendukung argumen mereka. Jika siswa diberi kebebasan dalam memilih topik, mereka akan mengurangi kebosanan guru ketika harus membaca (mengoreksi) pekerjaan mereka.

2. Pembimbingan menulis artikel opini hendaknya meliputi tiga tahap, 1) prapenulisan, 2) proses penulisan, dan 3) pascapenulisan. Guru tidak seharusnya membekali langkah-langkah 
menulis saja kemudian melepaskan siswa untuk pengembangan tulisannya.

3. Siswa seharusnya diarahkan untuk memublikasikan hasil karyanya agar bisa dibaca orang lain. Pemublikasian bisa dilakukan di media cetak, media daring, media sosial, majalah sekolah, blog sekolah, maupun blog pribadi.

\section{DAFTAR RUJUKAN}

Achmadi, M. (1988). Materi Dasar Pengajaran Komposisi Bahasa Indonesia. Jakarta: Depdikbud Direktorat Pendidikan Tinggi Proyek Pengembangan Lembaga Pendidikan Tenaga Kependidikan.

Arikunto, S. (2014). Prosedur Penelitian: Suatu Pendekatan Praktik. Jakarta: Rineka Cipta.

Hutabarat, S., \& Pudjomartono, S. (1995). "Menukik ke dalam artikel opini”. Dalam: Ashadi Siregar \& I Made Suarjana (eds). (1995). Bagaimana Mempertimbangkan Artikel Opini Untuk Media Massa. Penerbit Kanisius, Jakarta: 30-42.

Keraf, G. (1983). Argumentasi dan Narasi. Jakarta: Gramedia

Marahimin, I. (1999). Menulis Secara Populer. Jakarta: Pustaka Jaya

Nursito. (2000). Ikhtisar Kesusastraan Indonesia. Yogyakarta : Adicita Karya Nusa.

Susena, S. (1997). Teknik Penulisan Ilmiah Populer: Kiat Menulis Nonfiksi untuk Majalah. Jakarta: (Penerbit Gramedia, 1997: 104-105)

Soeparno. (2002). Dasar-Dasar Linguistik Umum. Yogyakarta: Tiara Wacana Yogya. 